Bangladesh J. Bot. 37(2): 141-147, 2008 (December)

\title{
SCREENING OF AROMATIC RICE LINES BY PHENOTYPIC AND MOLECULAR MARKERS
}

\author{
K. KIBRIa, M. M. ISLAM ${ }^{1}$ AND S. N. BEGUM ${ }^{1}$ \\ Department of Biotechnology, Bangladesh Agricultural University, \\ Mymensingh-2202, Bangladesh
}

Key words: Aromatic rice, Grain quality, Microsatellite marker

\begin{abstract}
To improve the yield potential of local aromatic variety Kalizira, a segregating population was developed from a cross between Y-1281 (high yielding mutant variety) and Kalizira. Thirty two $\mathrm{F}_{7}$ rice lines were used to evaluate agronomic characteristics, aroma detection through sensory test and genotypic analysis using microsatellite markers. Highly significant negative association was found between aroma and grain yield. Nine, 12 and 17 pedigree lines (PLs) having fragrance gene $(f g r)$ locus were found using three SSR markers RM223, RM342A and RM515, respectively as homozygous condition in 32 rice lines. The marker RM515 detected highest number of $f g r$ locus in PLs. Fourteen promising lines were identified with aroma genes having higher yield with good agronomic performance and other grain quality traits. These SSR markers could be utilized in marker-assisted selection (MAS) and would have a great impact on identifying fgr locus in rice genotypes.
\end{abstract}

\section{Introduction}

Rice (Oryza sativa L.) is the staple food of more than half of the world's population. Most of the world's rice is produced and consumed in Asia which constitutes more than half of the global population (Chakravarthi and Naravaneni 2006). In Bangladesh rice occupies about $70 \%$ of the total cropped area of about 13.9 million hectares. Out of this $70 \%$, fine rice is cultivated in roughly $10 \%$ land. Grain quality in rice plays an important role in consumer acceptability. Juliano and Duff (1991) concluded that grain quality is second after yield as the major breeding objective for crop improvement. The quality in rice is considered based on milling quality, grain size, shape, appearance, aroma and other cooking characteristics (Dela Cruz and Khush 2000). Most of the scented rice varieties in Bangladesh are of traditional type, photoperiod sensitive, and cultivated during the Aman season. Majority of these indigenous aromatic rice cultivars are low yielding but its higher price and low cost of cultivation generate higher profit margins compared to other varieties. Aroma development in rice grain is influenced by both genetic and environmental factors. The biochemical basis of aroma was identified as 2-acetyl-1-pyrroline (Tanchotikul and Hsieh 1991). Most of the rice varieties have been developed traditionally by selection, hybridization and back crossing with locally adapted high-yielding lines. The conventional methods of plant selection for aroma are not easy because of the large effects of the environment and the low narrow sense heritability of aroma. More recently molecular markers, such as SNPs and simple sequence repeats (SSRs), which are genetically linked to fragrance and have the advantage of being inexpensive, simple, rapid and only requiring small amounts of tissue, have been developed for the selection of fragrant rice (Cordeiro et al. 2002). Moreover, an allele specific amplification (ASA) assay allows discrimination between fragrant and non-fragrant rice varieties and identifies homozygous fragrant, homozygous non-fragrant and heterozygous nonfragrant individuals in a population segregating for fragrance (Louis et al. 2005). SSR or microsatellite markers behave as a co-dominant marker which was used for this study to select rice lines having aroma with fine grain and good seed yield.

${ }^{1}$ Plant Breeding Division, Bangladesh Institute of Nuclear Agriculture, Mymensingh-2200, Bangladesh. 


\section{Materials and Methods}

Plant materials: A segregating population was developed by crossing Y-1281 (a yigh yielding variety) with Kalizira (a local aromatic variety) for developing superior quality of aromatic rice lines at the Plant Breeding Division, Bangladesh Institute of Nuclear Agriculture (BINA), Mymensingh. Thirty two $\mathrm{F}_{7}$ pedigree lines along with their parents and a check variety, BRRIdhan 38 were used for phenotypic and genotypic study.

Phenotyping of rice germplasm: Five randomly selected plants of each genotype were used for agronomic data analysis. Data on plant height $(\mathrm{cm})$, number of effective tillers/plant, panicle length $(\mathrm{cm})$, number of filled grains/panicle, 1000 seed weight $(\mathrm{g})$, days to maturity and grain yield/plant (g) were recorded and subjected to statistical analyses using MSTATC software. After harvesting the seeds of each genotype were dehulled for evaluation of the grain quality viz. grain size (grain length), grain shape (grain length-breadth ratio) and aroma. The grains were classified into different types based on their dimension according to Dela Cruz and Khush (1989). Forty grains of each genotype were soaked in $10 \mathrm{ml} \mathrm{1.7 \%} \mathrm{KOH}$ solution at room temperature in a covered conical flask for about $1 \mathrm{~h}$. The samples were scored on 1-4 scale with 1, 2, 3 and 4 corresponding to absence of aroma, slight aroma, moderate aroma and strong aroma, respectively. The score for each sample was recorded by a panel of five experts who have experience in aromatic rice breeding and quality evaluation.

Molecular marker analysis: DNA isolation was carried out using the mini preparation CTAB method (IRRI 1997). Three SSR markers RM223, RM342A and RM515 (linked to aroma) were used to confirm the presence of $f g r$ gene as described by Garland et al. (2000) and Begum (2006). The details of the primers are given in Table 1 . The PCR reaction mixture contained $2 \mu 1$ of 50

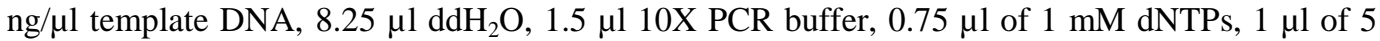
$\mathrm{M}$ forward and reverse primers and $0.5 \mu \mathrm{l}$ Taq Polymerase( $~ 2.5$ units/ 1). Template DNA was initially denatured at $94^{\circ} \mathrm{C}$ for 5 min followed by 30 cycles of PCR amplification following: $30 \mathrm{sec}$ of denaturation at $94^{\circ} \mathrm{C}, 30 \mathrm{sec}$ of primer annealing at $55^{\circ} \mathrm{C}$ and $1 \mathrm{~min}$ of primer extension at $72^{\circ} \mathrm{C}$. Final 5 min incubation at $72^{\circ} \mathrm{C}$ was allowed for complete of primer extension. The amplified products were electrophoretically resolved on a $1.5 \%$ agarose gel in $0.5 \mathrm{xTBE}$ and visualized under UV light after staining with ethidium bromide. The bands representing particular alleles at the microsatellite loci were scored manually on the basis of parental bands like aromatic type band (Kalizira), non-aromatic type (Y-1281) and heterozygotes type band (both).

Table 1. SSR markers for analysis of fragrance in rice.

\begin{tabular}{|c|c|c|c|c|c|c|}
\hline $\begin{array}{l}\text { Primer } \\
\text { name }\end{array}$ & $\begin{array}{l}\text { Size } \\
\text { range } \\
\text { (bp) }\end{array}$ & $\begin{array}{l}\text { Chrom. } \\
\text { locus }\end{array}$ & & Sequence & $\begin{array}{l}\text { Annealing } \\
\text { temp. } \\
\left({ }^{\circ} \mathrm{C}\right)\end{array}$ & Reference \\
\hline RM223 & $\begin{array}{l}139- \\
163\end{array}$ & 8 & $\begin{array}{l}\text { Rev. } \\
\text { Fwd. }\end{array}$ & $\begin{array}{l}\text { GAAGGCAAGTCTTGGCACTG } \\
\text { GAGTGAGCTTGGGCTGAAAC }\end{array}$ & 55 & $\begin{array}{l}\text { Temnykh } \\
\text { et al. } 2000\end{array}$ \\
\hline RM342A & n.a. & 8 & $\begin{array}{l}\text { Rev. } \\
\text { Fwd. }\end{array}$ & $\begin{array}{l}\text { ACTATGCAGTGGTGTCACCC } \\
\text { CСАTССТCСТАСTTCAATGAAG }\end{array}$ & 55 & $\begin{array}{l}\text { Temnykh } \\
\text { et al. } 2000\end{array}$ \\
\hline RM515 & $\begin{array}{l}205- \\
231\end{array}$ & 8 & $\begin{array}{l}\text { Rev. } \\
\text { Fwd. }\end{array}$ & $\begin{array}{l}\text { TGGCCTGCTCTCTCTCTCTC } \\
\text { TAGGACGACCAAAGGGTGAG }\end{array}$ & 55 & $\begin{array}{l}\text { Temnykh } \\
\text { et al. } 2001\end{array}$ \\
\hline
\end{tabular}

n.a. indicates not available in Gramene DNA database website and Temnykh et al. 2000.

\section{Results and Discussion}

Phenotypic evaluation of aromatic rice genotypes: The results on agronomic performance (Table 2) showed that the majority of the genotypes were superior to the local Kalizira variety. The plant height of the aromatic rice genotypes ranged from $96.2 \mathrm{~cm}$ (Y-1281) to $154.2 \mathrm{~cm}$ (PL7). In comparison to Kalizira, there were considerable reduction in plant height in most of the rice 
genotypes. The effective tillers/plant varied from 5.4 (PL32) to 15.6 (PL22). Eleven genotypes showed higher effective tiller number than that of Kalizira. Nine genotypes had longer panicles than both the parents. The number of filled grains/panicle was highest in PL26 (229.2) and lowest in PL17 (47.0). Twenty five genotypes had higher number of grains/panicle than the Kalizira parent. The 1000-grain weight was highest in PL11 (22.40 g) and lowest in PL23 (10.96 g). Days to maturity of the aromatic rice genotypes ranged from 108 (PL28, PL29) to 133 (Kalizira). Twelve genotypes showed higher grains/plant than both the parents.

Table 2. Agronomic, quality characteristics and genotypic analysis of $32 \mathrm{~F}_{7}$ rice lines along with parents and check.

\begin{tabular}{|c|c|c|c|c|c|c|c|}
\hline \multirow[b]{2}{*}{ Lines } & \multicolumn{4}{|c|}{ Agronomic and quality traits } & \multicolumn{3}{|c|}{ Genotypic analysis $^{2}$} \\
\hline & $\begin{array}{c}\text { Grain } \\
\text { yield/plan } \\
\mathrm{t}(\mathrm{g})\end{array}$ & $\begin{array}{c}\text { Grain length } \\
\text { (Grain size) } \\
\text { mm }\end{array}$ & $\begin{array}{c}\text { Grain length- } \\
\text { width ratio } \\
\text { (Grain shape) mm }\end{array}$ & Aroma $^{1}$ & RM223 & RM342A & RM515 \\
\hline PL1 & 19.02 & 6.95 & 3.30 & 3 & ++ & -- & ++ \\
\hline PL2 & 13.63 & 7.60 & 3.80 & 1 & -- & -- & +- \\
\hline PL3 & 13.91 & 6.85 & 3.04 & 3 & ++ & ++ & +- \\
\hline PL4 & 20.06 & 6.85 & 2.97 & 3 & +- & -- & +- \\
\hline PL5 & 13.37 & 7.25 & 3.37 & 4 & +- & -- & ++ \\
\hline PL6 & 11.32 & 7.25 & 3.29 & 4 & ++ & ++ & ++ \\
\hline PL7 & 11.64 & 7.10 & 3.38 & 3 & -- & -- & ++ \\
\hline PL8 & 23.27 & 7.00 & 3.25 & 3 & -- & -- & +- \\
\hline PL9 & 21.03 & 7.15 & 3.17 & 3 & ++ & -- & +- \\
\hline PL10 & 9.98 & 6.75 & 3.14 & 3 & +- & ++ & +- \\
\hline PL11 & 17.49 & 6.75 & 2.81 & 4 & +- & ++ & +- \\
\hline PL12 & 12.08 & 7.55 & 3.59 & 2 & -- & +- & ++ \\
\hline PL13 & 10.67 & 7.10 & 4.05 & 2 & +- & +- & ++ \\
\hline PL14 & 22.85 & 6.95 & 3.74 & 1 & +- & +- & ++ \\
\hline PL15 & 23.58 & 7.75 & 3.69 & 1 & -- & +- & ++ \\
\hline PL16 & 9.31 & 7.20 & 3.78 & 3 & ++ & +- & ++ \\
\hline PL17 & 7.52 & 7.00 & 3.41 & 3 & -- & +- & -- \\
\hline PL18 & 6.52 & 7.40 & 3.61 & 3 & -- & ++ & -- \\
\hline PL19 & 17.63 & 7.20 & 3.42 & 4 & -- & ++ & ++ \\
\hline PL20 & 11.50 & 7.00 & 3.11 & 3 & +- & ++ & ++ \\
\hline PL21 & 14.25 & 7.30 & 3.65 & 3 & ++ & +- & ++ \\
\hline PL22 & 24.08 & 7.35 & 3.41 & 3 & ++ & -- & ++ \\
\hline PL23 & 11.40 & 6.70 & 3.35 & 3 & -- & +- & -- \\
\hline PL24 & 11.18 & 7.00 & 3.88 & 1 & +- & +- & -- \\
\hline PL25 & 19.47 & 7.30 & 3.31 & 1 & +- & -- & ++ \\
\hline PL26 & 32.61 & 7.55 & 3.35 & 1 & +- & ++ & -- \\
\hline PL27 & 14.82 & 7.70 & 3.66 & 2 & -- & +- & -- \\
\hline PL28 & 12.00 & 7.00 & 3.68 & 1 & -- & +- & +- \\
\hline PL29 & 11.36 & 7.00 & 3.68 & 1 & +- & ++ & -- \\
\hline PL30 & 20.13 & 7.15 & 4.08 & 1 & -- & ++ & ++ \\
\hline PL31 & 12.40 & 7.00 & 3.78 & 1 & ++ & ++ & ++ \\
\hline PL32 & 8.73 & 7.00 & 3.33 & 3 & ++ & ++ & ++ \\
\hline Y-1281(P) & 15.36 & 7.75 & 3.69 & 1 & -- & -- & -- \\
\hline Kalizira(P) & 9.30 & 4.25 & 1.73 & 4 & ++ & ++ & ++ \\
\hline BRRIdhan-38 & 12.81 & 6.80 & 3.40 & 2 & ++ & ++ & ++ \\
\hline Range & $6.21-32.61$ & $4.25-7.75$ & $1.73-4.08$ & $1-4$ & & & \\
\hline Mean & 15.03 & 7.071 & 3.425 & 2.4 & & & \\
\hline
\end{tabular}

${ }_{1}^{1}$ = None; 2 = Slight; 3 = Moderate and 4 = Strong. ${ }^{2}++=$ Present of aroma gene; $--=$ Absent of aroma gene and $+-=$ Heterozygous condition. 
Thirty two advanced lines along with their parents and check variety were subjected to quality analysis. Six lines including parent Y-1281 had a desirable rice gain length of more than $7.5 \mathrm{~mm}$. Twenty eight lines were considered as long grain $(6.61-7.50 \mathrm{~mm})$. Kalizira had short grains of less than $5.50 \mathrm{~mm}$. Rice with kernel length of $7 \mathrm{~mm}$ or more and breadth of less than $2 \mathrm{~mm}$ are highly remunerative in international trade. Seven genotypes with these characteristics were observed in this study. The L/B ratio was higher than 3 (slender type) except in three genotypes (PL4, PL11 and Kalizira). Sharma (2002) mentioned that the aromatic cultivars possessed a slender shape compared with the medium-slender shape of non-aromatic cultivars. Most of the studied genotypes were found to give moderate and strong type aroma. Variation was observed among all the genotypes for different quality traits (Table 2 ).

Trait correlation: The correlation between traits was estimated by regressing phenotypic values of one trait on those of another trait. Pair-wise trait correlations are presented in Table 3. The significant positively correlated traits $(\mathrm{p}<0.001)$ included PH $\times$ PL $(0.370)$, PH $\times$ DM (0.348), PH $\times$ Aroma (0.476), PL $\times 1000 \mathrm{SW}(0.384), \mathrm{FG} \times \mathrm{GY}(0.612), 1000 \mathrm{SW} \times \mathrm{GY}(0.372)$ and DM $\times$ Aroma (0.295). A negative significant correlation was observed in FG $\times$ Aroma ($0.401)$ and GY $\times$ Aroma (- 0.256). Correlation studies between aroma and grain yield revealed that aroma is negatively correlated with grain yield. However, the usual yield of fine aromatic rice is low compared to high yielding varieties (Sarker 2002).

Table 3. Phenotypic correlations among yield related traits in Kalizira/Y-1281 derived $F_{7}$ population.

\begin{tabular}{lccccccc}
\hline Traits & $\begin{array}{c}\text { Panicle } \\
\text { length } \\
\text { (PL) }\end{array}$ & $\begin{array}{c}\text { Effective } \\
\text { tillers } \\
\text { (ET) }\end{array}$ & $\begin{array}{c}\text { Filled } \\
\text { grains } \\
(\mathrm{FG})\end{array}$ & $\begin{array}{c}1000-\text { seed } \\
\text { weight } \\
(1000-\mathrm{SW})\end{array}$ & $\begin{array}{c}\text { Days to } \\
\text { maturity } \\
(\mathrm{DM})\end{array}$ & $\begin{array}{c}\text { Grain } \\
\text { yield } \\
(\mathrm{GY})\end{array}$ & Aroma \\
\hline Plant height (PH) & $0.370^{* * *}$ & $-0.174^{*}$ & $-0.053^{\mathrm{ns}}$ & $0.036^{\mathrm{ns}}$ & $0.348^{* * *}$ & $-0.204^{* *}$ & $0.476^{* * *}$ \\
Panicle length (PL) & & $0.017^{\mathrm{ns}}$ & $0.118^{\mathrm{ns}}$ & $0.384^{* * *}$ & $0.213^{* *}$ & $0.151^{*}$ & $0.167^{*}$ \\
Effective tillers (ET) & & & $-0.053^{\mathrm{ns}}$ & $0.034^{\mathrm{ns}}$ & $0.007^{\mathrm{ns}}$ & $0.173^{*}$ & $0.118^{\mathrm{ns}}$ \\
Filled grains (FG) & & & & $0.233^{* *}$ & $-0.063^{\mathrm{ns}}$ & $0.612^{* * *}$ & $-0.401^{* * *}$ \\
1000-seed weight (1000-SW) & & & & $0.070^{\mathrm{ns}}$ & $0.372^{* * *}$ & $0.020^{\mathrm{ns}}$ \\
Days to maturity (DM) & & & & & & $-0.156^{*}$ & $0.295^{* * *}$ \\
Grain yield (GY) & & & & & & & $-0.256^{* * *}$ \\
\hline
\end{tabular}

ns indicates not significant, $*, * *, * * *$ significant at $<0.05,0.01$ and 0.001 , respectively.

Identification of fragrance (fgr) gene: Markers (RM223, RM342A and RM515) linked to aroma gene ( $f g r)$ selected on the basis of previous studies (Garland et al. 2000, Begum 2006) were found to be highly polymorphic between the parents in this study. Primer RM223 confirmed the presence of fragrance gene in 9 pedigree lines as parent Kalizira (aromatic type) at homozygous condition and 12 genotypes were identified as parent Y-1281 (non-aromatic type) as homozygous condition. Rest of the genotypes showed heterozygous condition (Table 2).

In case of RM342A, 12 lines gave aromatic banding pattern similar to Kalizira and the check variety, BRRIdhan-38 (Table 2). On the other hand, 9 lines had similar allele as non-aromatic parent Y-1281. Other genotypes showed heterozygous alleles. Eighteen lines showed aromatic alleles as Kalizira and check BRRIdhan-38 with RM515. Seven lines were found as non-aromatic allelic band like the parent Y-1281 and the rest of lines had heterozygous alleles (both Kalizira and Y-1281) (Fig. 1). 
In a previous study Begum (2006) reported that three markers RM223, RM342A and RM515 were located on chromosome 8 , found to be strongly associated ( $\mathrm{p}<0.0001)$ with aroma and explained 22.46, 28.38 and $41.78 \%$ of the total phenotypic variation. The SSRs, RM342, RM42, and RM223 showed a high degree of polymorphism between Basmati and non-Basmati type

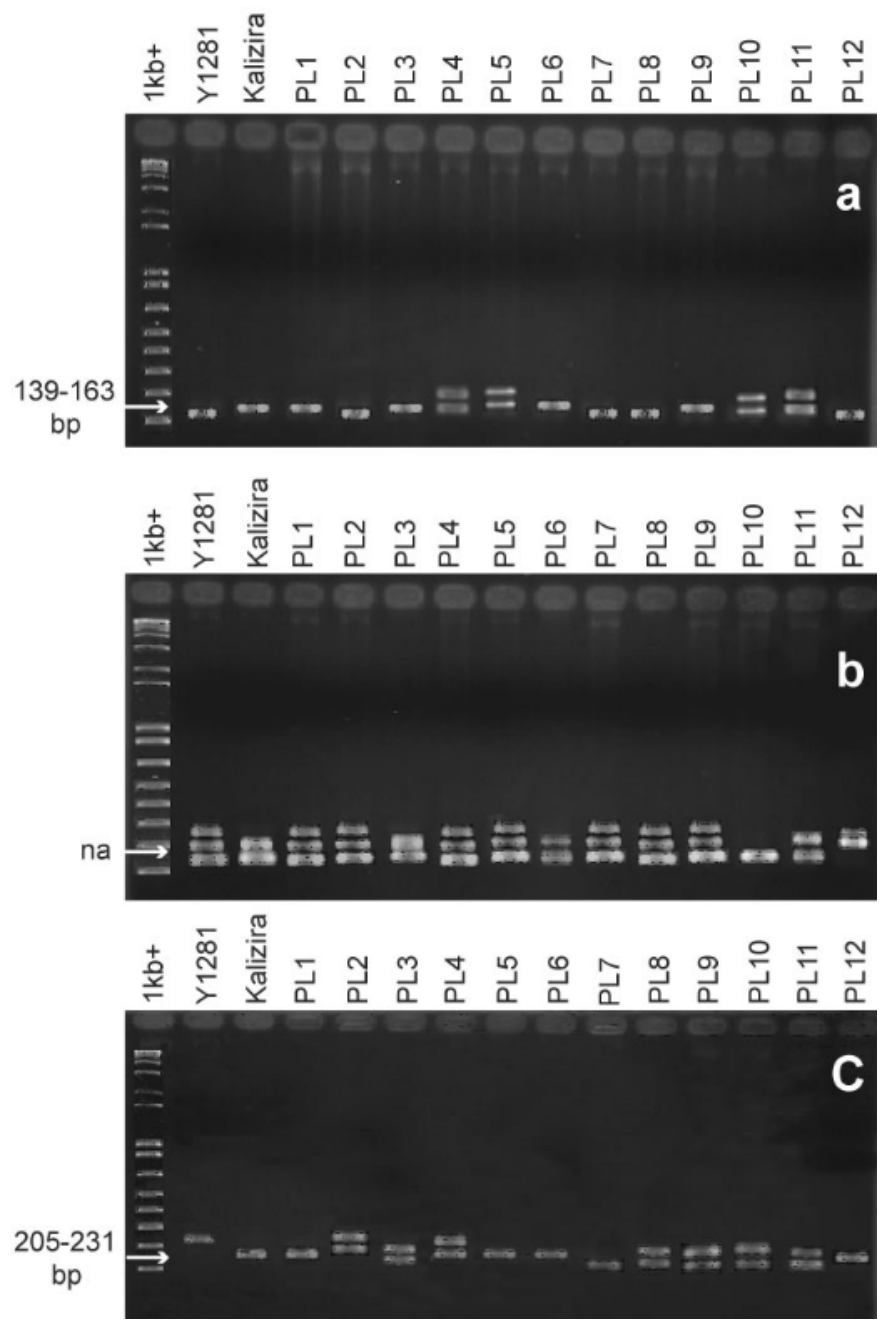

Fig.1. Banding pattern of some of the rice genotypes for a) RM223: single band like lane 2 non-aromatic (Y-1281); single band like lane 3 aromatic (Kalizira) and double band indicated heterozygous allele b) RM342A: triple band like lane 2 non-aromatic (Y-1281); double band like lane 3 aromatic (Kalizira) and single band indicated different allele of aroma gene than Kalizira c) RM515: same as "a", where Lane-1: 1 $\mathrm{kb}^{+}$ladder; Lane-2: Y-1281; Lane-3: Kalizira; Lane-4: PL1; Lane-5: PL2; Lane-6: PL3; Lane-7: PL4; Lane-8: PL5; Lane-9: PL6; Lane-10: PL7; Lane-11: PL8; Lane-12: PL9; Lane-13: PL10; Lane-14: PL11; Lane-15: PL12.

aromatic rice (Jain et al. 2004). Among 3 markers, RM223 could detect 9 pedigree lines having aroma while RM342A and RM515 identified 12 and 17 pedigree lines, respectively consisting aroma. RM223 and RM515 identified maximum lines (7 lines) having fgr locus that is responsible for aroma with RM515 detecting the highest number of lines. Bradbury et al. (2005) stated that 
RM515 which is mapped at the same position as RM223 explained more variation for aroma than even RM223. Obviously the present results are in agreement with these findings. Considering phenotypic and genotypic observations, four lines, PL5, PL6, PL11 and PL19 having fgr gene also have strong aroma, higher grain yield, very long and slender grain. Eleven lines i.e. PL1, PL3, PL7, PL9, PL10, PL16, PL18, PL20, PL21, PL22 and PL32 were found to have moderate aroma, having $f g r$ gene locus, different grain yield, and very long to slender grain. Rest of lines had slight to no aroma and absence of fragrance gene allele. PL6 and PL32 were identified as aromatic rice lines by three markers as well as phenotypic evaluation. On the other hand, PL31 was identified as aromatic rice line by using three markers but phenotypically aroma was not detected, although this line have considerable grain length, length-breadth ratio and yield. This might have happened due to error in scoring phenotype that cannot be avoided with the effect of environment, especially aroma (Lang and Buu, 2002). Based on the study, 14 lines (PL1, PL3, PL5, PL6, PL9, PL10, PL11, PL16, PL19, PL20, PL21, PL22, PL31 and PL32) having good aroma and superior agronomic performance have been selected in $\mathrm{F}_{7}$ generation. The result having aroma in selected rice lines were confirmed by both phenotypic and genotypic analysis. These selected pedigree lines could be used as donors for future breeding programmes that aim to develop aromatic rice varieties.

\section{Acknowledgements}

The authors are grateful to Dr. Md. Ali Azam, Principle Scientific Officer, Plant Breeding Division, Bangladesh Institute of Nuclear Agriculture (BINA), Mymensingh, for kindly providing the $\mathrm{F}_{7}$ aromatic rice lines used in the present investigation.

\section{References}

Begum, S.N. 2006. Development of Basmati-derived rice lines for grain quality and resistance to bacterial blight. Ph.D. Thesis. Bangladesh Agric. Univ., Mymensingh. pp. 215.

Bradbury, L.M.T., T. Fitzgerald, R.J. Henry, Q. Jin and D.L.E. Waters. 2005. The gene for fragrance in rice. Plant Biotech. J. 3: 163-370.

Chakravarthi, B.K. and R. Naravaneni. 2006. SSR marker based DNA finger-printing and diversity study in rice (Oryza sativa L.). African J. Biotech. 5(9): 684-688.

Cordeiro, G.M., M.J. Christopher, R.J. Henry and R.F. Reinke. 2002. Identification of microsatellite markers for fragrance in rice by analysis of the rice genome sequence. Mol. Breed. 9(4): 245-250.

Dela, Cruz N. and G.S. Khush. 2000. Rice grain quality evaluation procedures. In: Aromatic rices. Singh, R.K., Singh, U.S. and Khush, G.S. (Eds). Oxford \& IBH Publishing Co. Pvt. Ltd., New Delhi, India, pp.16-28.

Dela, Cruz N., I. Kumar, R.P. Kaushik and G.S. Khush. 1989. Effect of temperature during grain development on the performance and stability of cooking quality components of rice. Japan J. Breed. 39: 299-306.

Garland, S., L. Lewin, A. Blakeney, R. Reinke and R. Henry. 2000. PCR-based molecular markers for the fragrance gene in rice (Oryza sativa. L.). Theor. Appl. Genet. 101: 364-371.

IRRI (International Rice Research Institute). 1997. Rice Almanac. IRRI-WARDA-CIAT, Los Banos, Laguna, Philippines.

Jain, N., N. Saini, P. Rana, S. Jain and R.K. Jain. 2004. Microsatellite diversity for chromosome number 8 in Basmati rice. RGN 19: 103-105.

Juliano, B.O. and D. Duff. 1991. Rice grain quality as an emerging priority in National rice breeding programmes. In: rice grain marketing and quality issues. Los Banos, Laguna, IRRI. pp. 55-64.

Lang, N.T. and B.C. Buu. 2002. Identification and fine mapping of SSR marker linked to $f g r$ gene of rice. OmonRice 10: 16-22. 
Louis, M.T.B., J.H. Robert, J. Qingsheng, F.R. Russell and L.E.W. Daniel. 2005. A perfect marker for fragrance genotyping in rice. Mol. Breed. 16: 279-283.

Sarker, M.A.H. 2002. Indigenous Fine Aromatic Rice Production: Bangladesh Perspective. 12-15 November 2002. Development of Basic Standard for Organic Rice Cultivation. $1^{\text {st }}$ RDA/ARNOA International Conference. RDA and Dankook Univ., Korea.

Sharma, N. 2002. Quality characteristics of non-aromatic and aromatic rice varieties in Punjub. Indian J. Agric. Sci. 72(7): 408-410.

Tanchotikul, U. and T.C.Y. Hsieh. 1991. An improved method for quantification of 2-acetyl-1-pyrroline a popcorn-like aroma, in aromatic rice by high-resolution gas chromatography/ mass chromatography/ selected ion monitoring. J. Agric. Food Chem. 39: 944-947.

(Manuscript received on 13 March, 2008; revised on 13 October, 2008) 